\title{
The Orthodox Neo-Patristic Movement's Encounter with the Christian 'Other': An Ecumenical Hermeneutics of Receptivity
}

\begin{abstract}
This article discerns an ecumenical hermeneutics of receptivity towards Western theology in the writings of the Orthodox Neo-patristic author Dumitru Stăniloae (1903-1993). In so doing, the article shows that, despite its rejection of Western scholasticism, the program of the Orthodox Neo-patristic movement also included an ecumenical component which, instead of cultivating opposition between Eastern and Western Christianity, invited churches to dialogue and mutual enrichment. The exploration of Stăniloae's notion of 'open sobornicity' is the main focus of this article.
\end{abstract}

\section{Keywords}

Dumitru Stăniloae, ecumenism, Neo-patristic movement, open sobornicity, Orthodox theology

The Neo-Patristic movementı was the most influential theological direction in $20_{\text {th-century }}$ Orthodox Christianity. It consisted of a large group of Orthodox thinkers who advocated the

I See Paul Ladouceur, Modern Orthodox Theology: 'Behold, I Make All Things New' (London: T\&T Clark, 2019), 95-I22; Idem, "Treasures New and Old: Landmarks of Orthodox Neopatristic Theology," St. Vladimir's Theological Quarterly 56:2 (20I2): 191-228; Viorel Coman, “Revisiting the Agenda of the Neo-Patristic Movement," The Downside Review I38:2 (2018): 99-II7; Christos Filiotis-Vlachavas, "La théologie orthodoxe, entre retour aux pères et appel de la modernité,” Revue des sciences religieuses 89:4 (20I5): 425-442; loan I. Ică jr., “Modern and Contemporary Orthodox Theology: Key Moments, Key Figures, Developments, and Assessments," in V. loniță (ed.), Orthodox Theology in the 20th Century and Early $2 I_{\text {st }}$ Century: A 
need of Eastern theology to return to the patristic sources of Christianity in order to renew itself and depart from the negative influences of Western scholasticism, which had permeated its ecclesiology, ethics, and spirituality for centuries. Initiated in the 1930s in the Russian Parisian diaspora by Georges Florovsky (1893-1979),2 the Neo-patristic movement continued in the US, UK, France, Greece, and other Eastern Orthodox countries through the writings of theologians such as Justin Popović (I894-1979), Vladimir Lossky (1903-1958), Dumitru Stăniloae (1903-1993), Alexander Schmemann (1921-1983), John Meyendorff (1926-1992), John Romanides (1927-200 I), Panagiotis Nellas ( 1936-1986), John Zizioulas (b. 193 I), Kallistos Ware (b. 1934), and Christos Yannaras (b. 1935). Georges Florovsky's call for a return ad mentem patrum 3 had been so widely shared by his colleagues that the search for a Neopatristic synthesis in Eastern Christian theology reached the point of dominating the Orthodox scene in the second half of the 20 th century.

However, at the turn of the $2 I_{\text {st }}$ century, the enthusiasm generated by the Neopatristic movement in Orthodoxy has gradually and rightly started to be tempered by a series of scholars such as Pantelis Kalaitizidis, Brandon Gallaher, John Behr, Cyril Hovorun, Aristotle Papanikolaou, Paul Gavrilyuk, and many others. Their criticism has called into question the monopoly of the Neo-patristic movement in Eastern theology and the following basic tenets of its agenda: (i) the Neo-patristic movement's claim that Hellenism is the perennial philosophical category of Christianity, which leaves little room for inculturation and for the

Romanian Orthodox Perspective (Bucharest: Basilica, 2013), 21 -94; Andrew Louth, "The Patristic Revival and Its Protagonists," in M. B. Cunningham and E. Theokritoff (eds.), The Cambridge Companion to Orthodox Christian Theology (Cambridge: Cambridge University Press, 2008), I88203.

2 Paul Ladouceur and Brandon Gallaher (eds.), The Patristic Witness of Georges Florovsky: Essential Theological Writings (New York, NY: T\&T Clark, 2019); Paul Gavrilyuk, Georges Florovsky and the Russian Religious Renaissance: Changing Paradigms in Historical and Systematic Theology (Oxford: Oxford University Press, 20I3); Idem, "The Epistemological Contours of Florovsky's Neo-Patristic Synthesis,” Journal of Eastern Christian Studies, 69:I-4 (2017): I-24.

${ }_{3}$ Georges Florovsky, “Westliche Einflüsse in der russischen Theologie," in H. Alivisatos (ed.), Procès-verbaux du premier congrès de théologie orthodoxe à Athènes, 29 novembre-6 décembre 1936 (Athens: Pyrsos, 1939), 2I2-23I; Idem, "Patristic and Modern theology," in H. Alivisatos (ed.), Procès-verbaux du premier congrès, 238-242. 
transposition of Christian truth into the language of contemporary philosophy and culture; (ii) the role played by the Neo-patristic agenda in the consolidation of anti-Western and antiecumenical attitudes in the Orthodox world. The quest to 'de-Westernize' Orthodox theology had a side effect: it inevitably led to a stronger polarization between East and West; (iii) the Neo-patristic movement's tendency to see the theology of the Church Fathers as a harmonious and perfectly symphonic system of thought, which pays less or no attention to individual voices and to the many disagreements existing between the Church Fathers on several doctrinal issues; (iv) the relatively poor interest of the Neo-patristic movement in the study of Scriptures, which explains the neglect of biblical studies in modern and contemporary Orthodoxy; and (v) the Neo-patristic theology's weak engagement with the many challenges brought by modernity and post-modernity. 4

As indicated above, one of the main aspects of the Neo-patristic agenda that has severely been criticized by scholars over the past decades refers to its discourse vis-à-vis Western Christianity: the Neo-patristic movement's primary objective (liberation of Eastern Christian theology from Western scholastic patterns of thought) has easily led to the growth of anti-ecumenical feelings in some Eastern Christian circles and to the development of a politics of identity in which Orthodoxy defines itself in opposition to the West.5 The antiecumenical and anti-Western attitudes generated by the Neo-patristic movement are mainly

${ }_{4}$ Pantelis Kalaitzidis, "From the 'Return to the Fathers' to the Need for a Modern Orthodox Theology," St. Vladimir's Theological Quarterly, 54:I (2010), 5-36; B. Gallaher, “'Waiting for the Barbarians': Identity and Polemicism in the Neo-Patristic Synthesis of Georges Florovsky," Modern Theology 27:4 (201 I): 659-69I; John Behr, "Reading the Fathers Today," in J. Mihoc and L. Aldea (eds.), A Celebration of Living Theology: A Festschrift in Honour of Andrew Louth (London: T\&T Clark, 20 I4), 7-19; Cyril Hovorun, "Patristics after Neo-Patristic, in J. Mihoc and L. Aldea (eds.), A Celebration of Living Theology, 205-2। 3; Aristotle Papanikolaou, "Tradition or Identity Polemics: The Role of the 'West' in Contemporary Orthodox Theology," in I. Tulcan, C. loja, M. Stavrou, and P. Bouteneff (eds.) Tradition and Dogma: What Kind of Dogmatic Theology Do We Propose for the Present? (Arad: Editura Universității 'Aurel Vlaicu', 2010), 242-250; Gavrilyuk, "Florovsky's Neopatristic Synthesis and the Future of Orthodox Theology," in G. Demacopoulos and A. Papanikolaou (eds.), Orthodox Constructions of the West (New York, NY: Fordham University Press, 2013), 102-124.

5 Papanikolaou, “Tradition or Identity Polemics," 242. 
- although not exclusively - the by-products of its major axis of interaction with Western Christianity, which operates with a hermeneutics of rejection: one has to reject the influences of $B$ (primarily Western scholasticism) to establish the pristine ethos of $A$ (Orthodox theology). Closer study, however, shows that, despite its implicit anti-Western and antischolastic orientation, the agenda of the Neo-patristic movement also included an ecumenical component, which has not received due attention until recently. In an article published in 2014, the late Matthew Baker uncovered to a certain extent the ecumenical dimension of the Neo-patristic program as put forth by Georges Florovsky, Vladimir Lossky, and John Zizioulas.7 This article continues the approach of Baker and reveals the ecumenical leanings of another giant of the Neo-patristic movement: the Romanian theologian Dumitru Stăniloae. In so doing, it argues that Stăniloae's writings provide Eastern theology with another guiding axis of interaction with the West along that which seeks to liberate Orthodoxy from foreign influences. This axis, which is enclosed in Stăniloae' concept of 'open sobornicity', instead of cultivating a stronger polarization between East and West, is a hermeneutics of receptivity: one establishes $A$ not in opposition to $B$ but in dialogue with $B$ and mutual enrichment.

The main goal of this article to shed light on the ecumenical component of the Neopatristic movement has a threefold relevance: it shows that, when looking at individual theologians such as Stăniloae, (i) the interaction of the Neo-patristic movement with Western theology cannot be simply reduce to its task of liberating Orthodoxy from Latin scholasticism; there is more than that in the Neo-patristic agenda than opposition to Western Christianity, be it Catholicism or Protestantism; (ii) the Neo-patristic movement struggled to keep a

${ }_{6}$ For a comprehensive analysis of the main factors that led to the consolidation of an antiWestern rhetoric in contemporary Orthodoxy, see P. Kalaitzidis, "Theological, Historical, and Cultural Reasons for Anti-Ecumenical Movements in Eastern Orthodoxy," in P. Kalaitzidis et alii (eds.), Orthodox Handbook on Ecumenism: Resources for Theological Education (Volos: Volos Academy Publications, 2014), I34-I52; Vasilios Makrides, "Orthodox Anti-Westernism Today: A Hindrance to European Integration?" International Journal for the Study of the Christian Church 9:3 (2009): 209-224.

7 Matthew Baker, “Neopatristic Synthesis and Ecumenism: Toward the 'Reintegration' of Christian Tradition," in A. Krawchuk and T. Bremer (eds.), Eastern Orthodox Encounters of Identity and Otherness: Values, Self-Reflection, Dialogue (New York, NY: Palgrave Macmillan, 20I4), 235-260. 
balance between twin fidelities: on the one hand, faithfulness to the Orthodox identity; on the other hand, openness to the Christian 'other'; and (iii) his hermeneutics of receptivity could serve as a source of inspiration for ecumenical openness and mutual dialogue between Christian traditions, especially in the current Eastern Christian context marked by the escalation of anti-ecumenical feelings as well as by the growth of anti-Western political and theological propaganda.

\section{Dumitru Stăniloae’s Interaction with Western Theology}

Dumitru Stăniloaes is widely considered to be one of the most important $20_{\text {th-century }}$ Orthodox theologians and a towering figure of the Neo-patristic movement. In the opinion of Kallistos Ware, the Romanian theologian "occupies a position in present-day Orthodoxy comparable to that of Karl Barth in Protestantism or Karl Rahner in Catholicism.”9 Stăniloae is the author of an impressive theological corpus of II 50 titles, which includes more than 20 books, 33 translations, and hundreds of articles. A few of his most important publications are as follows: The Immortal Image of God (1987), 10 Spirituality and Communion in the Orthodox Liturgy

${ }_{8}$ For an excellent presentation of Stăniloae's biography, see the following works: Lidia lonescu Stăniloae, Lumina faptei din lumina cuvântului: împreună cu tatăl meu, Dumitru Stăniloae [The Light of Deed from the Light of the Word: Together with My Father, Dumitru Stăniloae] (București: Editura Humanitas, 2000); Dumitru Stăniloae and Marc-Antoine Costa de Beauregard, Dumitru Staniloae: ose comprendre que je t’aime (Paris: Cerf, 1983); A. Louth, “Modern Orthodox Dogmatic Theology: Dumitru Stăniloae," in Modern Orthodox Thinkers: From the Philokalia to the Present (London: SPCK, 2015), 127-142; Andrei Ștefan Stroia, "Dumitru Staniloae," in Augustine Casiday (ed.), The Orthodox Christian World (London: Routledge, 20I2), 352-358; loan I. Ică jr., "Dumitru Stăniloae (1903-1993)," in T. Hart (ed.), The Dictionary of Historical Theology (Grand Rapids, MI: Eerdmans, 2000), 527-53I; Daniele Neeser, “Elementi biobibliografici," in Dumitru Staniloae, Dio è amore: Indagine storico-teologica nella prospettiva ortodossa (Roma: Città Nuova, 1986), 6-16.

9 Kallistos Ware, “Foreword," in Dumitru Stăniloae, The Experience of God, Vol. I: Revelation and Knowledge of the Triune God, trans. loan lonita and Robert Barringer (Brookline, MA: Holy Cross Orthodox Press, 1998), xxiv.

10 Stăniloae, Chipul nemuritor al lui Dumnezeu, Opere Complete 5 (București: Basilica, 2013). 
(1986), , Orthodox Spirituality (198I), 12 Orthodox Dogmatic Theology in 3 volumes (1978-1979), 13 Jesus Christ and the Restoration of Humankind (1943), 14 and The Life and Teaching of St. Gregory Palamas (1938).15 Unlike most representatives of the Neo-patristic movement such as Florovsky, Lossky, Schmemann, and Meyendorff, who lived and activated in the West, Stăniloae spent most of his life behind the Iron Curtain; and it is precisely this isolation that makes his approach to Western theology more interesting. As in the case of other Neopatristic luminaires, Stăniloae's position vis-à-vis Western Christianity requires nuance.

On the one hand, Stăniloae's conviction that Orthodoxy renews itself if it escapes the influences of Western scholasticism and returns to the patristic ethos made him quite critical of some aspects of Roman Catholic and Protestant theology; but his criticism was largely directed against Neo-scholasticism and the transformations it has brought in theology: overemphasis on rational speculations to the detriment of apophaticism, separation between academic theology and spirituality; elaboration of an ecclesiology understood in predominantly legal and institutional categories, etc. As Radu Bordeianu rightly noticed, Stăniloae "engaged mostly with Catholic and Protestant theologies of the late nineteenth and early twentieth centuries [...], which he encountered early in life as a student in the West. These theologies are frequently criticized by modern Catholic theologians too." 16 It is true that very often Stăniloae's criticism of Western theology turned into exaggerations and

II Stăniloae, Spiritualitate și comuniune în liturghia ortodoxă (București: Editura Institutului Biblic și de Misiune al Bisericii Ortodoxe Române, 2004). French translation: Spiritualité et communion dans la liturgie orthodoxe (Paris: Editions Lithielleux, 2017).

12 Stăniloae, Spiritualitatea ortodoxă: ascetica și mistica, Opere Complete 13 (București: Basilica, 2019). English translation: Orthodox Spirituality: A Practical Guide for the Faithful and a Definitive Manual for the Scholar (South Canaan, PA: St. Tikhon's Seminary Press, 2003).

13 Stăniloae, Teologia dogmatică ortodoxă, vol. I-III, Opere Complete 10-I2 (București: Basilica, 2018). English translation: The Experience of God: Orthodox Dogmatic Theology, 6 vols. (Brookline, MA: Holy Cross Orthodox Press, 1998-2013).

${ }_{14}$ Stăniloae, lisus Hristos sau restaurarea omului, Opere Complete 4 (București: Basilica, 20I3). 15 Stăniloae, Viața și învățătura sfântului Grigorie Palama (București: Editura Institutului Biblic și de Misiune al Bisericii Ortodoxe Române, 2006).

${ }_{16}$ Radu Bordeianu, Dumitru Staniloae: An Ecumenical Ecclesiology, Ecclesiological Investigation I3 (London: T\&T Clark, 20II), 20-2I. 
adopted a virulent rhetoric, venturing thoughts of confessional hostility. However, in a similar way to other Neo-patristic voices, Stăniloae's criticism of Roman Catholicism and Protestantism did not eventuate in anti-Westernism and anti-ecumenism, which - as Paul Ladouceur pointed out - would reject "Western theology a priori, and for that matter, all forms of Western culture." In fact, "issue-oriented critique of specific Western theological doctrines is more characteristic of modern Orthodox theology [including Stăniloae] than systematic anti-Westernism.” ${ }_{17}$ Nevertheless, it must be also said that Stăniloae's criticism of Western theology reached its peak during the 1950s and 1960s; towards the end of the 1970s, when Stăniloae was allowed by the communist regime to travel West and take part in ecumenical gatherings, he started adopting a more conciliatory language and toned down his previous harsh criticism of Roman Catholic and Protestant theology. 18 Such a change in Stăniloae's approach was also noticed by André Scrima in a private correspondence with Pierre Duprey. 19

On the other hand, even though Stăniloae was severely critical of aspects of Western theology, he always remained open to dialogue and conversation with the Roman Catholic and Protestant traditions, ready to learn and to receive from them. This is to say that a hermeneutics of ecumenical receptivity and openness also guided Stăniloae's interaction with the traditions of Western Christianity. As Donald Allchin pointed out, Stăniloae "had no doubt about the centrality of Orthodoxy in the Christian world and he sought constantly to articulate the fullness and balance of the Orthodox vision of faith. But for him that vision was always an open and inclusive thing, never something closed and exclusive." 20 Therefore, there was a second axis that structured Stăniloae's encounter with the West, which consisted of a

17 Ladouceur, Modern Orthodox Theology, 424.

${ }_{18}$ V. Coman, Dumitru Stăniloae’s Trinitarian Ecclesiology: Orthodoxy and the Filioque (Lanham, MD: Lexington Books/Fortress Academic), I4-I5; Ronald Roberson, "Dumitru Stăniloae on Christian Unity," in L. Turcescu (ed.), Dumitru Stăniloae: Tradition and Modernity in Theology (lași: The Center For Romanian Studies, 2002), II3; R. Bordeianu, Dumitru Staniloae: An Ecumenical Ecclesiology, 21.

19 "Letter to Pierre Duprey, 24 October 197I," in FDuprey 4.I58. The Duprey archives are to be found in the library of the Fundazione per le science religiose Giovanni XXIII, Bologna.

20 Donald Allchin, “Dumitru Staniloae (1903-1993)," Sobornost I6:I (1994): 43 [emphasis mine]. 
genuine engagement in dialogue with Roman Catholic and Protestant theology, as well as of a willingness on his part to listen to other Christian traditions in order to absorb their spiritual and theological riches. As a matter of fact, even though Stăniloae believed that the revitalization of modern Orthodox theology can be achieved through a patristica restauratio and liberation from the influences of Western scholasticism, he did not consider that Eastern Christianity should remain hermetically closed to the positive influences of Roman Catholic and Protestant traditions. He knew to recognize and appreciate the legitimate values of other Christian traditions that could enrich Orthodox theology. That being so, due to his important academic service for the cause of ecumenism, in 1995 the two editors of the volume titled Ecumenical Pilgrims: Profiles of Pioneers in Christian Reconciliation decided to include Stăniloae on the list of the $20_{\mathrm{th}}$-century personalities who have "inspired, by their work, writings, and example, the search for unity and renewal."21 The name of Stăniloae rightly stands in the book along those of other ecumenical giants such as Patriarch Athenagoras I, Pope John XXIII, Cardinal Augustine Bea, Dom Lambert Beauduin, Yves Congar, Cardinal Johannes Willebrands, just to mention but a few of them.

It is to the more theoretical foundation of Stăniloae's second axis of interaction with Western theology that this article now turns. This theoretical foundation is illustrated at best by the Romanian theologian's concept of 'open sobornicity or catholicity'. Brief information about the theological and political context in which Stăniloae developed the notion of 'open sobornicity' precedes the analysis of the concept and its implications.

21 Ion Bria and Dagmar Heller (eds.), Ecumenical Pilgrims: Profiles of Pioneers in Christian Reconciliation (Geneva: WCC Publications, 1995), 226-230. The Ecumenical profile of Stăniloae has been explored by several scholars: R. Bordeianu, Dumitru Staniloae: An Ecumenical Ecclesiology, I3-40; V. Ioniță, “Contribuția părintelui Dumitru Stăniloae la dialogul ecumenic [Fr. Dumitru Stăniloae's Contribution to the Ecumenical Dialogue]," Anuarul Facultății de Teologie Ortodoxă 'Justinian Patriarhul' din București închinat memoriei părintelui Dumitru Stăniloae cu prilejul împlinirii a 100 de ani de la naștere [The Yearbook of the 'Justinian the Patriarch' Faculty of Orthodox Theology, University of Bucharest. Volume Dedicated to the Centenary of Dumitru Stăniloae] (București: Editura Universității din București, 2004), 87-95; István Jusház, “Dumitru Stăniloae's Ecumenical Studies as an Aspect of Orthodox-Protestant Dialogue," Journal of Ecumenical Studies 16:4 (1979): 747-764. 


\section{‘Open Sobornicity’: An Ecumenical Hermeneutics of Receptivity}

The concept of 'open sobornicity' [sobornicitatea deschisă], as developed by Stăniloae in the 1970s, is a method of ecumenical interaction which permeated the entire theological vision of the Romanian author. An extensive presentation of this concept was offered by Stăniloae in an article he published in 1971: "Open Sobornicity." 22 But even though the article from 1971 is the most detailed analysis of the notion of 'open sobornicity', two other important studies of him briefly touched the issue: "The Coordinates of Ecumenism from an Orthodox Perspective" (1967);23 and "The Problems and Perspectives of Orthodox Theology” (1972).24

The elaboration of the concept of 'open sobornicity' in Stăniloae's theology followed up the decision of the Romanian Orthodox Church, as well as of other Orthodox Churches, to become a member of the World Council of Churches and to send official delegates to its Third General Assembly in New Delhi in 196I. The notion of 'open sobornicity' was, therefore, meant by Stăniloae to foster the rapprochement between Christian Churches and to offer Orthodox theology a tool that could stimulate and assist its ecumenical engagement. Needless to say, the Romanian Orthodox Church's determination to join the WCC in I96I

22 Stăniloae, "Sobornicitatea deschisă," Ortodoxia 23:2 (197I): 165-I80. Secondary literature on the topic of 'open sobornicity' has lately started to grow: V. Coman, “'Open Sobornicity' and 'Receptive Ecumenism': Fruitful Models of Ecumenical Interaction,” in D. Heller and M. Hietamaki (eds.), Just Do It? Recognition and Reception in Ecumenical Relations: Proceedings of the 19th Academic Consultation of the Societas Oecumenica, Beihefte zur Ökumenischen Rundschau II7 (Leipzig: Evangelische Verlagsanstalt), 24I-25I; Idem, “Le Saint Esprit comme liaison de l'amour éternel entre le Père et le Fils: un cas de 'sobornicité ouverte' dans la théologie orthodoxe," Irénikon 89:I (20I6): 25-5I; R. Bordeianu, “(In)Voluntary Ecumenism: Dumitru Staniloae's Interaction with the West as Open Sobornicity," in G. Demacopoulos and A. Papanikolaou (eds.), Orthodox Constructions of the West, 240-253; L. Turcescu, "Eucharistic Ecclesiology or Open Sobornicity?” in L. Turcescu, Dumitru Stăniloae, 83-103.

23 Stăniloae, "Coordonatele ecumenismului din punct de vedere ortodox [The Coordinates of Ecumenism from the Orthodox Perspective]" Ortodoxia 19:4 (1967): 494-540.

24 Stăniloae, "Problemele și perspectivele teologiei ortodoxe," Altar Almanah 2 (I97|-1972): 40-50; English translation by Robert Barringer: D. Stăniloae, Theology and the Church (Crestwood, NY: St. Vladimir's Seminary Press, 1980), 213-226. 
came also as a result of the Romanian communist political system's signs of openness towards the West at the moment when the Cold War was at its peak.25 This is to say that the attempts of the Romanian communist regime to develop closer economic and political ties with the West and to develop a line of national autonomy after a decade of intense Sovietization of the country (1944-1958) explain in great part the intensification of the relationships of the Romanian Orthodox Church with the World Council of Churches and the Roman Catholic Church. It is true that the Romanian Orthodox Church and its theologians followed in fact the agenda of the state; but their interest in ecumenism was genuine, especially since a new era in the relationships between the Orthodox Church and the Catholic Church was inaugurated by the Second Vatican Council, after centuries of mutual hostilities, animosities, and distrust. As a matter of fact, the new ecumenical orientation of the Romanian Orthodox Church gave an impulse to Stăniloae to offer Orthodoxy "a rich instrument and working method" 26 of dialogue with the other Christian traditions.

But what does the notion of 'open sobornicity' exactly mean? In brief, in the concept of 'open sobornicity' "every theological system and tradition are welcome as offering some valid insights, although the weaknesses of each must be criticized [...] Through openness to the insights of other theological systems and Christian traditions, one's own understanding is enriched, and a more symphonic understanding of the whole is attained." 27 In other words, the concept of 'open sobornicity' is a "tool to foster an authentic ecumenical dialogue without running the risk of doctrinal relativism.” 28 To fully grasp Stăniloae's concept of 'open

${ }_{25}$ For a comprehensive introduction into the relationship between the Romanian Orthodox

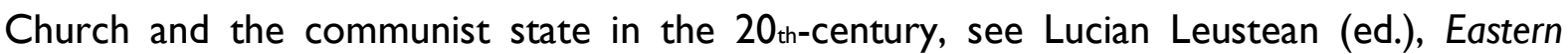
Christianity and the Cold War, 1945-199I (London: Routledge, 2010); Idem, Orthodoxy and the Cold War: Religion and Political Power in Romania, 1947-1965 (London: Palgrave Macmillan, 2009); Kaisamari Hintikka, The Romanian Orthodox Church and the World Council of Churches, 196I-1977 (Helsinki: Luther-Agricola-Society, 2000); Olivier Gillet, Religion et nationalisme: Pidéologie de l'Église Orthodoxe Roumaine sous le régime communiste (Bruxelles: Éditions de l'Université de Bruxelles, 1997).

26 Ștefãniță Barbu, “Dumitru Stăniloae,” in P. Kalaitzidis et alii (eds.), Orthodox Handbook on Ecumenism, 250.

27 Turcescu, "Eucharistic Ecclesiology or Open Sobornicity?" I0I-I02.

28 Turcescu, "Eucharistic Ecclesiology or Open Sobornicity?" 102. 
sobornicity' and the rationale that stands behind its claim that Orthodoxy should remain open to the theological and spiritual riches of other Christian traditions, the following theological aspects need to be considered:

(i) Stăniloae's understanding of the notion of 'sobornicity'; and

(ii) the two main hermeneutical principles that guided Stăniloae's claim that the Church's sobornicity involves openness and receptivity towards other Christian traditions.

The Sobornicity of the Church: Unity in Complementary Variety

Etymologically, the notion of sobornyi/sobornaya represents the Medieval Slav translation of the Greek expression $\kappa \alpha \vartheta ั \lambda \iota \kappa \dot{\eta}$ (catholic) in the Nicene-Constantinopolitan Creed: $\kappa \alpha \vartheta \circ \lambda \iota \kappa \dot{\eta}$ $\varepsilon \dot{\varepsilon} \kappa \lambda \eta$ i $\alpha \alpha$ sobornaya tser'kov. The adjective sobornyi/sobornaya comes from the noun sobor ('synod', 'council', 'synaxis') and is related to the verbs sobirat and beru ('gather', 'gathering', 'bringing and assembling together'). Although sobornaya/sobornost is a Russian word with no exact English translation, the closest equivalent would be 'catholicity', 'conciliarity,' 'collegiality,' and 'synodality.' 29 The Greek koinonia is also a near equivalent.30 The first Orthodox thinker to place the notion of sobornaya at the center of his ecclesiological

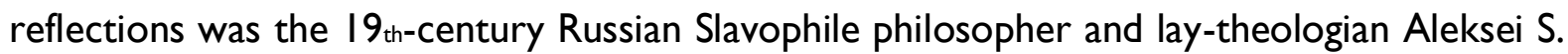
Khomiakov (I804-I860), for whom, "sobonaya was not only a correct translation [of

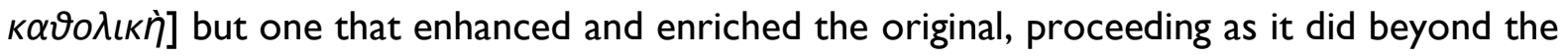
quantitative aspect of catholicity and universality to an emphasis on quality." ${ }_{1}$ For Khomiakov and his disciples, sobornaya encapsulates a vision of the Church as an organic synthesis of unity and diversity, and as the perfect harmony between personal liberty and collective unanimity:

29 Elizabeth A. Livingstone (eds.), The Oxford Dictionary of the Christian Church, Third Edition (Oxford: Oxford University Press, 1998), 15II-15I2; Dominique Le Tournau, Le mots du Christianism: Catholicisme, Orthodoxie, Protestantisme (Paris: Fayard, 2005), 588.

30 Anthony C. Thiselton, The Thiselton Companion to Christian Theology (Grand Rapids, MI: Eerdmans, 20I5), 782.

31 Sergei Hackel, "Sobornost," in Nicholas Lossky et alii (eds.), Dictionary of the Ecumenical Movement (Geneva: WCC Publications, 1991), 925. 
"a unity of persons in a loving fellowship in which each member retains freedom and integrity without excessive individualism." 32

Stăniloae's reflections on the sobornicity of the Church drew heavily on Khomiakov for inspiration. Despite the Romanic origin of the Romanian language that makes it less receptive to Slavic influences, Stăniloae preferred the notion of 'sobornicity' to that of 'catholicity', although there were moments when he used both terms interchangeably. Very often, Stăniloae made deliberate use of a number of synonyms to render the meaning of 'sobornicity': 'synodality', 'communion', 'unity in diversity', 'symphonic diversity of the Church'.33 In 1977, Stăniloae attempted to replace the word 'sobornicity' with 'synodicity' in the vocabulary of the Romanian Orthodox Church.34 In 1978, however, without any explanation, he abandoned the idea and started using again the old notion of 'sobornicity'.

In Stăniloae's theological thinking, the notion of 'sobornicity' is the most perfect expression of the idea that the Church is the life of communion based on unity in complementary diversity. As Stăniloae pointed out, sobornicity defines the fact that the Church is "a unity of persons in complementary variety. If through the attribute of unity the

32 John Simpson and Edmund Weiner (eds.) The Oxford English Dictionary, vol. XV (Oxford: Calderon Press, 1989), 903. For an excellent introduction into Khomiakov's theology of sobornost/sobornaya, see: Sorin Șelaru, Biserica și bisericile: modele eclesiologice ortodoxe în perspectivă intercreștină [The Church and the Churches: Orthodox Ecclesiological Models in an InterChristian Perspective] (București: Editura Universității din București, 2015), 13-35; Kallistos Ware, "Sobornost and Eucharistic Ecclesiology: Aleksei Khomiakov and His Successors," International Journal for the Study of the Christian Church II:2-3 (20II): 216-235; Peter Vogt, "The Church as Community of Love According to Alexis S. Khomiakov," St. Vladimir's Theological Quarterly 48:4 (2004): 393-4I4; Joost van Rossum, “A.S. Khomiakov and Orthodox Ecclesiology," St. Vladimir's Theological Quarterly 35:I (1991): 67-82.

${ }_{33}$ Stăniloae borrowed the notion of the Church as a symphony of persons from Georges Florovsky. See G. Florovsky, The Body of the Living Christ: An Orthodox Interpretation of the Church (New York, NY: The Wheel, 2018), 40 [originally published in French in 1948].

34 Stăniloae, "Natura sinodicității [The Nature of Synodicity]," Studii Teologice 29:9- 10 (1970): 605-6I4. A similar attempt was undertaken in the 1930s by G. Florovsky, who proposed the term communality: “The Limits of the Church," Church Quarterly Review II7: 233 (1933): II7|3I. See also S. Șelaru, The Church and the Churches, 39. 
fact that the Church is one is simply affirmed, then through the attribute of sobornicity we see what the nature of this unity is. It is a unity achieved and maintained through the convergence, communion, and unanimous complementary of its members." 35

For the Romanian theologian, the sobornicity of the Church is the opposite of a uniform, homogeneous, and undifferentiated whole that washes away plurality and diversity. Sobornicity is, therefore, a special kind of unity which preserves the distinctiveness of its members or parts, without falling into individualism and privatism. Additionally, the notion of 'sobornicity' translates the idea that the Church is "an organic whole, and organism or spiritual body, a plenitude that has everything. And this everything, plenitude, is present and efficient in each of its members, acts, and parts," 36 but only inasmuch as that member or part remains in the communion of the Church. In this regard, the sobornicity of the Church conveys the meaning of a spiritual body in which its members receive the fullness of life from the whole organism and contribute with their specificities and gifts to the whole organism's richness and plenitude. According to Stăniloae, sobornicity is a mark of the Church which is to be realized on each and every level of its existence: in the individual life of each Christian, in the life of a local ecclesial community, and in the manifestation of the Church's universal unity. 37 When properly embodied and lived, sobornicity renders the Body of Christ into a sort of a "permanent synod" 38 or council.

For Stăniloae, the sobornicity of the Church is founded on a threefold basis: first of all, the sobornicity of the Church has an anthropological foundation: the unity of human nature in a diversity of persons. Every human person hypostasizes and lives human nature in a way

${ }_{35}$ Stăniloae, The Experience of God. Vol. IV: The Church, Communion in the Holy Spirit (Brookline, MA: Holy Cross Orthodox Press, 2012), 79-80.

${ }_{36}$ Stăniloae, The Experience of God, vol. IV, 80.

${ }_{37}$ For Stăniloae, sobornicity is like a 'law' that governs the entire life of the Orthodox Church. See his article titled "Temeiurile teologice ale ierarhiei și ale sinodalității [The Theological Foundations of Hierarchy and Synodality]," Studii Teologice 22:3-4 (1970): 169. A similar idea on sobornicity is shared by John Meyendorff. See his article "The Catholicity of the Church," St. Vladimir's Theological Quarterly 17:1-2 (1973): 5-18. The article has been republished in Meyendorff's book titled Living Tradition (Crestwood, NY: St. Vladimir's Seminary Press, 1978), $81-97$.

${ }_{38}$ Stăniloae, The Experience of God, vol. IV, 80. 
that is unique to himself/herself and complementary to others. This complementarity means that nobody can live in complete solitude and isolation, because the fulfillment of the human person involves communion with other human fellows. When the communion between persons is diminished or completely disappears, persons become individuals, i.e., entities affirmed by way of contrast to, rather than of communion with other human beings. According to Stăniloae, "whoever falls away from this sobornicity [communion] falls away into a shadow of existence." 39 Secondly, the sobornicity of the Church is founded on the doctrine of the Trinity, who is the supreme mystery of unity in diversity.40 Stăniloae's reference to the Trinitarian basis of the sobornicity of the Church seems to echo Vladimir Lossky's claim that "as in God there is no one nature apart from the Three persons so in the Church there is no abstract universality but a complete harmony of catholic diversity. As in God each one of the Three persons, Father, Son, and the Holy Spirit, is not a part of the Trinity but is fully God [...], so the Church is not a federation of parts: it is catholic in each one of its parts, since each part in it is identified with the whole, expresses the whole, has the value that the whole has, does not exist outside the whole." 4 I Last but not least, the sobornicity of the Church is founded on Christology and pneumatology, for the preservation of ecclesial unity in diversity is not simply the product of human endeavor but the work of Christ and the Spirit. In communion, diversities are brought together in harmony as gifts of the Spirit of Christ. As Stăniloae pointed out, "the Spirit is present wholly in every member by a different gift, or by way of mutually interdependent gifts which neither make all members the same nor allow them to work in isolation from one another, for no single member remains unconditioned by the others." He continued by saying that the Spirit "binds men to one another and creates in each an awareness of belonging to all the rest." 42

${ }_{39}$ Stăniloae, The Experience of God. Vol. II: The Experience of God. Vol. II: The World, Creation and Deification (Brookline, MA: Holy Cross Orthodox Press, 2000), 142.

40 Stăniloae, "Natura sinodicității [The Nature of Synodicity]," 606.

4I Lossky, In the Image and Likeness of God (Crestwood, NY: St. Vladimir's Seminary Press, 1974), 179-180; Stăniloae, "The Holy Spirit and the Sobornicity of the Church," in D. Stăniloae, Theology and the Church, 64-65. The article was originally published in Romanian: “Duhul Sfânt și sobornicitatea bisericii,” Ortodoxia 19:I (1967): 32-48.

42 Stăniloae, "The Holy Spirit and the Sobornicity of the Church," 54-55; Idem. "Duhul Sfânt în revelație și în biserică [The Holy Spirit in Revelation and in the Church]," Ortodoxia 26:2 
Most of what Stăniloae had to say on the sobornicity of the Church found deep inspiration in the writings of Khomiakov and his Russian disciples from the Parisian diaspora.43 And yet there is still something new and extremely interesting that the Romanian theologian added to the already-existing Orthodox reflections on the sobornicity of the Church: the idea that ecclesial sobornicity has an open dimension, which means that the Church needs to recognize God's working presence even outside its canonical borders and to strive to realize its unity in complementary diversity without betraying the great gifts of God's grace that flourish in non-Orthodox churches and communities. This openness - as John Meyendorff said echoing Stăniloae's theology of sobornicity - implies receptivity and attentiveness "to all manifestations of God's creating and redeeming power everywhere," 44 which is a recognition and acceptance into the life of the Orthodox Church of what is legitimate diversity, authentic, and right everywhere, be it in other Christian churches, religions, and the world at large. In other words, 'open sobornicity' is a life of communion as unity in complementary diversity extended beyond the borders of Orthodoxy to embrace the genuine experience of God as lived by other churches and cultures. Stăniloae's vision of an 'open sobornicity' relies on two hermeneutical principles.

(1974): 216-249; Idem, "Trinitarian Relations and the Life of the Church," in D. Stăniloae, Theology and the Church, II-44. Stăniloae's reflections on Christ and the Spirit as factors of both unity and diversity bear witness to his attempt to work out a balanced synthesis between Christology and pneumatology in ecclesiology.

${ }_{43}$ Florovsky, "The Catholicity of the Church," in E. Mascall (ed.), The Church of God (London: S.P.C.K., 1934), 53-74; Idem, “The Church: Her Nature and Her Task," in The Universal Church in God's Design: An Ecumenical Study Prepared under the Auspices of the World Council of Churches, vol. I (New York, NY: Harper, 1948), 43-58; Sergius Bulgakov, The Orthodox Church (London: Centenary Press, 1935); V. Lossky, The Mystical Theology of the Eastern Church (Crestwood, NY: St. Vladimir's Seminary Press, 1976) [originally published in French in 1944]. Even Afanasiev's Eucharistic ecclesiology is influenced by Khomiakov's notion of 'sobornost': $\mathrm{N}$. Afanasiev, The Church of the Holy Spirit (Notre Dame, IN: University of Notre Dame, 2007); Aidan Nichols, Theology in the Russian Diaspora: Church, Fathers in Nikolai Afanas'ev, 1893-1966 (Cambridge: Cambridge University Press, 2008).

44 John Meyendorff, “The Catholicity of the Church: An Introduction," St. Vladimir's Theological Quarterly I7:I-2 (1973): I2; D. Stăniloae, “Open Sobornicity,” I7I. 
The Eastern Christian doctrine of human growth in communion with God as a continuous process of spiritual development is the first of the two main hermeneutical principles that underpin Stăniloae's understanding of sobornicity as an open and all-embracing reality, which encourages the Orthodox Church to go beyond its confines and to engage with the revealed truth as differently lived and conceptualized outside its strict canonical and dogmatic boundaries. The emphasis on the human growth in communion with God runs like a red thread throughout Stăniloae's corpus of writings and translates into more commonlyaccessible terms Orthodox concept such as deification, christification, or theosis: the doctrine of human union with God by grace without annulment neither of the ontological distinction between creature and Creator nor of the diversity within creation.45 What is directly relevant for our discussions of the notion of 'open sobornicity' is that, in Stăniloae's theology, deification or communion has a twofold dimension: deification of the human person; and deification of the Church as a whole.

Roughly speaking, Stăniloae understands the deification of the person as the human being's advancement into a life of fellowship with God and as its ongoing ecclesial journey for spiritual perfection and flourishment on a higher level of existence; and it is within this life of communion and fellowship with God in the Church that the human person can find its fulfillment as a unique and unrepeatable existence.46 For Stăniloae, personal advancement in

${ }_{45}$ For a comprehensive introduction into Stăniloae's theology of theosis or deification, see the following books and articles: Emil Bartoș, Deification in Eastern Orthodox Theology: An Evaluation and Critique of the Theology of Dumitru Stan̆iloae (Carlisle, Cumbria: Paternoster Press, 1999); Idem, “The Dynamics of Deification in the Theology of Dumitru Stăniloae,” L. Turcescu (ed.), Dumitru Stăniloae, 207-248; See also the two articles recently written by Petre Maican, “An Eastern Orthodox Ecumenical Hermeneutics: Dumitru Stăniloae on Interpreting the Fathers in an Ecumenical Context," I-24. Unpublished paper presented at the Annual Conference of the European Academy of Religion, Bologna, 5-8 March 2018; Idem, "Why Ecumenical Dialogue Matters for the Orthodox Church,” in D. Heller and M. Hietamaki (eds.), Just Do It?, 289-298.

${ }_{46}$ Stăniloae, The Experience of God, Vol. I, 9; Idem, Studii de teologie dogmatică ortodoxă [Studies in Orthodox Dogmatic Theology] (Craiova: Editura Mitropoliei Olteniei, 1990), I57-I72. 
communion with God is proportional with personal progress in knowledge of the divine: there is growth in communion and fellowship with God as long as there is progress in knowledge of God, thereby the human person "freely and consciously assimilates the infinite spiritual richness of the supreme Personal reality." 47 The more one knows God the more intimate to the divine that person is. Moreover, personal deification involves horizontal relationality and conversation in the sense that no personal progress in communion with God is being made unless there is openness and receptivity towards alterity, i.e., the other members of the Church and the rest of creation.48 Personal openness towards other human beings and the rest of creation means advancement in communion with God and deification because it equally represents personal advancement in knowledge of God. This is to say that human persons finds God fully, and progresses in the relationship with the divine reality, only if they also search for the manifestations of God in the life of other beings and let themselves be enriched by their unique and genuine experiences of the divine.

In Stăniloae's theology, the guiding tenets of the personal model of deification, which involves attentiveness to alterity and to God's revelatory actions in the life of other human beings, are extrapolated to a macro level: as long as it finds itself in history, the Eastern Orthodox Church as a whole is also constantly invited to advance on its path to an even deeper communion with God and to assimilate more fully the spiritual riches of the divine life. Moreover, as in the case of the human person, whose deification is a dialogical process, the gradual advancement of the Orthodox Church in communion with God cannot and must not remain an internal and self-sufficient process, without any concern for the way in which the genuine experience of God as lived and interpreted by other churches and traditions can contribute to Orthodoxy's growth in knowledge of the divine reality. For Stăniloae, throughout this continuous process of advancement in deification and knowledge of God, the Orthodox Church has the duty to incorporate into its own life the authentic spiritual and theological richness of other churches and Christian communities, as the Orthodox Church's openness to and assimilation of their genuine acquisitions enriches its understanding of God and helps it progress in communion with the divine reality. It is important to mention at this point that, even though Stăniloae subscribed to the idea that the Orthodox Church is the Una

${ }_{47}$ Stăniloae, The Experience of God, Vol. I, 9.

48 Stăniloae, "The Nature of Synodicity," 612; Idem, "The Theological Foundations of Hierarchy," I72-I73. 
Sancta,49 he did not fail to acknowledge that other churches and even the world at large enjoy degrees of ecclesiality and partake to a certain extent of the divine truth, given their relationship with Christ and his salvific presence in them.50 That being so, Stăniloae considered that the basic principles of the notion of sobornicity as unity in complementary variety renders the Orthodox Church's growth in communion with God dependent upon its willingness to allow its own experience of the divine be enlarged by the way in which the light of the Gospel has authentically flourished in other traditions and has been differently embodied by other nations and people outside the canonical boundaries of Orthodoxy. For this reason, Stăniloae defined the notion of sobornicity as follows: "sobornicity in the full sense of the word is the active bringing to fruition by all Christians [...] of the full treasures of truth and life brought by Christ." ${ }_{51}$ Or, "[sobornicity] has to be the gathering (sobor) of the whole world, where all Christians bring together their understanding of the whole revealed divine reality and of the

49 "The Church in the full sense of the word is the Orthodox Church [...] Those confessions [other Christian churches] have gained in part the quality as churches of Christ, being called to their full realization as the Church of Christ" - Stăniloae, The Experience of God, vol. IV, 6667. Stăniloae's claim that other Christian churches are not completely devoid of ecclesiality is shared by a large number of theologians: In fact, John Jillions considers that $20_{\text {th-century }}$ Eastern Christian theologians developed three major views on the ecclesiality of other churches: (a) Traditionalist: approach promotes an ecumenism of return and claims that all other Christian bodies are defective and cannot be called churches; (b) Mainstream views (D. Stăniloae, G. Florovsky, etc.): the Orthodox Church embodies the fullness of truth but it does not have a monopoly on truth; (c) Prophetic approach (S. Bulgakov, N. Afanasiev, etc.): proposed prophetic actions towards Christian unity such as full intercommunion of the Orthodox Church with the Roman Catholic Church and the Anglican Church - John Jillions, "Three Orthodox Models of Christian Unity: Traditionalist, Mainstream, Prophetic," International Journal of the Study of the Christian Church 9:4 (2009): 295-3II. See also the excellent article of B. Gallaher, "Ecumenism as Civilisational Dialogue: Eastern Orthodox AntiEcumenism and Eastern Orthodox Ecumenism. A Creative or Sterile Antinomy," International Journal for the Study of the Christian Church (forthcoming). The article is already available online at https://www.tandfonline.com/doi/full// 0.1080//474225X.2019.1595827

${ }_{50}$ Stăniloae, The Experience of God, vol. IV, 66-67.

51 Stăniloae, “The Coordinates of Ecumenism,” 516. 
whole human reality in the light of the integral revelation." 52 However, for Stăniloae, open sobornicity does not mean the accumulation or the integration in the life of the Orthodox Church of any type of experience or the enjoyment of any insight coming from outside Orthodox Christianity. The practice of discernment is therefore important in any interaction with other Christian churches and in the act of learning and receiving from them.

\section{The Eschatological Principle}

Stăniloae's notion of 'open sobornicity', which invites Orthodox Christianity to embrace the theological and spiritual values of other Christian churches, is also guided by an eschatologically oriented approach. In fact, Stăniloae's eschatologically oriented approach to sobornicity is connected to and sheds light upon his emphasis on the dynamic character of human communion with God. That being so, Stăniloae's fidelity to a hermeneutics of eschatology 53 is visible at best in his elaboration on the notion of 'sobornicity' in connection to the Church's call to permanently grow in its understanding of God. But how does eschatology explain Stăniloae's claim that the Orthodox Church, which, in his understanding, possesses the treasury of truth and teaching entrusted to her by Jesus Christ for the salvation of human beings, needs the theological insights and the exchange of spiritual experiences in togetherness with other Christian churches?

52 Stăniloae, “Open Sobornicity,” 172.

${ }_{53}$ Stăniloae is not the only 20th-century Orthodox theologian who uses a hermeneutics of eschatology in his writings. See Pantelis Kalaitzidis, "Eschatology and Future-Oriented Hermeneutics in Contemporary Orthodox Theology: The Case of Metropolitan John Zizioulas," in Reimund Bieringer, Peter De Mey, Ma. Marilou S. Ibita, and Didier Pollefeyt (eds.), The Spirit, Hermeneutics, and Dialogue, Annua Nuntia Lovaniensia 76 (Leuven: Peeters, 2019), I55-180; Matthew Baker, "Being, Interpretation, and the Last Things: Eschatological Ontology and Hermeneutics in Heidegger and Zizioulas," Unpublished paper presented at International Conference: Ontology and History, May 2015, Delphi, Greece; J. Zizioulas, Remembering the Future: An Eschatological Ontology (London: Bloomsbury, forthcoming). Elements of a future-oriented hermeneutics are also present in the writings of Savas Agourides, Alexander Schmemann, John Meyendorff, Nikos Nissiotis, Olivier Clément, and Nicholas Berdiaev. 
For Stăniloae, the Orthodox Church possesses the truth of revelation because it possesses Christ and is the continuation of Christ's presence throughout history (incarnatio continua). .54 However, the Church is already and not yet in the possession of Christ's plenitude or fullness. The Orthodox Church is the fullness or the plenitude of Christ "in a certain potential state but in motion or progress toward the full actualization in the eschaton." ${ }_{55}$ Even though the Orthodox Church is the possessor of Christ's salvific presence and revelation, the Orthodox Church in its totality advances towards an eschatological fullness of the complete experience of God and of its total integration in the mystery of Christ, when God will be all in all and our knowledge of the Triune God will be made complete. For this reason, as long as it lives in history, the Orthodox Church must not attach itself to all forms of knowledge of God it possesses and to all the instances of God's revelation in history as to the final reality. 56 The knowledge of God as experienced in history in the sobornicity of the Orthodox Church is something which needs to remain open, transparent, and "continuously surpassed, because all are penultimate." ${ }_{57}$ It is therefore only in the eschaton that the Church will enjoy the plenitude of truth and have the full grasp of God. The knowledge of God as lived now by the Orthodox Church is open in the sense that the Church finds itself in a continuous process of growth in knowledge; it is transparent in the sense that it has an iconic character: it does not exhaust the mystery of God but only points towards its eschatological fullness; it is continuously surpassed because as long as the Church finds itself on its way towards the Kingdom, our "knowledge of God is fragmentary and has a degree of relativity." 58 Relativity does not mean that there is no certainty about the truth the Church has been given by Christ; it rather means that, prior to the eschaton, truth is not static but dynamic.

On its way towards the Kingdom and the full knowledge of God, the Orthodox Church could benefit greatly from practicing 'open sobornicity', because openness to the genuine theological insights of other Christian traditions, which means the integration of their authentic experiences of God and their legitimate knowledge of him into its own life, increases

${ }_{54}$ V. Coman, "The Sacramentality of the Church in Dumitru Stăniloae's Theology," Pro Ecclesia 27:2 (20 I8): 203-224; Idem, Dumitru Stăniloae’s Trinitarian Ecclesiology, I 3 I - 65.

${ }_{55}$ Stăniloae, The Experience of God, vol. IV, 85.

${ }_{56}$ Stăniloae, “Open Sobornicity," 173.

${ }_{57}$ Stăniloae, “Open Sobornicity," 173.

${ }_{58}$ Stăniloae, “Open Sobornicity," 173. 
the Orthodox understanding of Christ, shedding light upon theological aspects neglected by the Orthodox Church but more fully affirmed by other traditions and in other contexts.59 In fact, such an advancement in knowledge increases the Orthodox Church's spiritual experience of Christ and moves the Church towards the eschaton, that is, to the moment when the unity of all humankind in God will be the moment of God's full revelation and of our plenary knowledge of him. Since the progress towards the Kingdom is in fact a progress in communion with God and with the whole of creation, as well as an advancement in knowledge of God, the Orthodox Church must deepen such a communion and knowledge not in opposition to the experience of Christ's work and revelation in other traditions but in communion and cooperation with them. This is why Stăniloae claims that "Orthodox sobornicity nowadays must be enriched with the spiritual values actualized by Western Christians.”60 In light of what has been said above, Stăniloae even admitted the existence of a sort of theological pluralism within the Church.61

Without any exaggeration, one can say that the two hermeneutical principles that underpin Stăniloae's notion of 'open sobornicity' testifies to a form of 'receptive ecumenism' avant la letter in the writings of the Romanian theologian. According to Paul Murray, who is the architect of the concept, 'receptive ecumenism' promotes a learning model of ecumenical

59 Stăniloae claims that Orthodox theology's openness to Roman Catholicism could give Eastern Christianity an impulse to consolidate and strengthen even more its visible unity, although not in the sense of adopting a system similar to that of pope's primacy. Given the many problems confronting the Orthodox Church after the Council of Crete (2016) and the recent ecclesial crisis in Orthodox Ukraine (2018-2019), Stăniloae's remark is not devoid of importance. In Stăniloae's opinion, Orthodoxy could learn from Protestant theology to give more value to all instances of God's revelation in history. See Stăniloae, "Open Sobornicity," 176. The need of Orthodox theology to learn from Western Christianity is also emphasized by the American theologian John A. Jillions. See his article "Orthodox Christianity in the West: The Ecumenical Challenge," in Mary B. Cunningham and Elizabeth Theokritoff (eds.), The Cambridge Companion to Orthodox Christian Theology (Cambridge: Cambridge University Press, 2008), 276-291.

60 Stăniloae, “Open Sobornicity," 171.

${ }_{61}$ "This sobornicity that is open, transparent, and continuously surpassed, also implies a certain theological pluralism” - Stăniloae, “Open Sobornicity,” 178. 
interaction 62 on the path towards Christian unity. For Murray, the many divisions and tensions between churches can be attenuated as long as Christian churches remain in conversation and dialogue, ready to receive from one another. Even though Stăniloae's notion of 'open sobornicity' is an ecumenical model which combines mutual giving and receiving between churches, it testifies to a form of 'receptive ecumenism' in the sense that it shows crucial interest in the gifts of God shown in the Christian other, as well as in the role of this receiving process, which leads a church towards a deeper understanding of its own identity and mission. In this regard, 'open sobornicity' offers original insights anyone interested in receptive ecumenism, as Stăniloae provided theology with two relevant hermeneutical principles that explain why the Christian other needs to be regarded as the necessary locus of and the absolute condition for the understanding of one's own tradition and identity. Stăniloae's theology testifies to a form of 'receptive ecumenism'; but it is Metropolitan Kallistos Ware who fully explored the ecumenical potential of Murray's concept from an Orthodox perspective and showed how it works in the domains of ecclesiology, ecology, and anthropology.63

\section{Implementation}

The previous section of this article has dealt with the theoretical foundations of Stăniloae's methodology of ecumenical conversation and has sketched out its hermeneutical principles that encourage Orthodoxy to engage itself in dialogue and exchange with other Christian churches. Unquestionably, Stăniloae's concept of 'open sobornicity' remains a substantial contribution to ecumenical dialogue, as it represents a much more complex understanding of the role and task of the Orthodox Church in any encounter with other Christian traditions than one can find in the writings of the large majority of Eastern theologians in the 20th century. In Stăniloae's understanding, the Orthodox Church does not simply engage in

62 Paul Murray (ed.), Receptive Ecumenism and the Call to Catholic Learning: Exploring a Way for Contemporary Ecumenism (Oxford: Oxford University Press, 2008); Idem, "Receptive Ecumenism and Ecclesial Learning: Receiving Gifts for our Needs,” Louvain Studies 33:I-2 (2008): 30-45.

${ }_{63}$ K. Ware, “Receptive Ecumenism: An Orthodox Perspective,” Louvain Studies 33:I -2 (2008): 46-54. 
dialogue with other traditions to give a trustworthy witness to the truth in the fullness and precision of the apostolic faith embodied by Eastern Christianity; 64 there is more than that in any ecumenical dialogue, namely the process of learning from the others. But Stăniloae did not only offer theoretical considerations about Orthodoxy's need to go beyond its boundaries and let itself be enriched by other Christian traditions; he also equipped Orthodox theology with the practice of 'open sobornicity'.

First of all, Stăniloae implemented the practice of 'open sobornicity' as an active participant in various ecumenical meetings, where he significantly contributed to the interChristian dialogue and had his theological views enriched by his interlocutors. Stăniloae took part in the following major ecumenical gatherings:65 (i) Addis-Abeba (19-29 August 197I) the first official meeting of the Eastern Orthodox Church with the non-Chalcedonians; (ii) Goslar (1979), lași (1980), Hüllhorst (1982) - the first three official meetings between the Romanian Orthodox Church (BOR) and the Evangelischen Kirche in Deutschland (EKD);

${ }_{64}$ Gennadios Limouris book entitled Orthodox Visions of Ecumenism: Statements, Messages and Reports on the Ecumenical Movement 1902-1992 (Geneva: WCC, 1994) is a good example in this regard, for it considers that the task of the Orthodox Church in the ecumenical movement is to give witness to the fullness of truth.

${ }_{65}$ For a more detailed presentation of Stăniloae's participation in the ecumenical movement, see: Ciprian Toroczkai, "Toward an Expanded Formula of the Chalcedonian Dogmatic Definition? Fr. Dumitur Staniloae's Contribution to the Dialogue with Non-Chalcedonian Churches," Greek Orthodox Theological Review 59:I-4 (2014): 45-160; Idem, "Father Dumitru Stăniloae and the Ecumenical Dialogue,” Ecumenical Review 5:3 (2013): 339-373; S. Șelaru, “Contribuția părintelui Stăniloae la primul document teologic al comisiei mixte de dialog teologic intre Biserica romano-catolică și Biserica ortodoxă [The Contribution of Fr. Dumitru Stăniloae to the First Theological Document of the International Commission for Theological Dialogue between the Roman Catholic Church and the Orthodox Church," Anuarul Facultății de Teologie Orthodoxă, Universitatea București [The Yearbook of the Faculty of Orthodox Theology, University of Bucharest] (București: Editura Universității din București, 2013), 297-309; V. Ioniță, “Contribuția părintelui Dumitru Stăniloae la dialogul ecumenic [The Contribution of Fr. Dumitru Stăniloae to the Ecumenical Dialogue]," Anuarul Facultății de Teologie Orthodoxă, Universitatea București [The Yearbook of the Faculty of Orthodox Theology, University of Bucharest] (București: Editura Universității din București, 2004), 87-93. 
Klingenthal (1978-1979) - ecumenical consultation organized by the Faith and Order Commission to discuss the filioque issue; Munich (1982) - the second plenary meeting of the International Theological Commission for the Dialogue between the Orthodox Church and the Roman Catholic Church. Scholars who have analyzed how Stăniloae's thought has evolved over a decades-long career emphasized the positive impact of these ecumenical gatherings upon his theology. For example, both the Klingenthal consultation and the Munich meeting have produced a positive change in his attitude towards the Roman Catholic Church, especially in regard to the issue of the filioque and its ecclesiological implications. This is an example of 'open sobornicity' in the sense that Stăniloae allowed his previous assumptions on the doctrine of the filioque be revised and even corrected to a certain extent by the positions of his Western partners of dialogue.66

Second, Stăniloae's practice of 'open sobornicity' went beyond his active participation in ecumenical meetings, for it also came to light in the Romanian author's abundant use of Western theological and philosophical sources, as well as in the incorporation into his writings of theological themes proper to Roman Catholicism. For example, his theological writings are deeply infused with ideas taken from Western thinkers, ranging from Søren Kierkegaard, Odo Casel, Mathias Scheeben, Martin Buber, and Maurice Blonder to Martin Heidegger, Henri de Lubac, Yves Congar, Karl Rahner, Karl Barth, Emil Brunner, and Jürgen Moltmann, just to name but a few of them. The role played by these Western theologians and philosophers in shaping his theological edifice can hardly be ignored. More importantly, Western theological motifs were also creatively appropriated by his theology: (i) Rahner's transcendental Christology;67 (ii) The Augustinian depiction of the Holy Spirit as the loving tie between the Father and the Son, without subscribing though to the doctrine of the filioque; 68 (iii) the

${ }_{66}$ See the following works: Coman, Dumitru Stăniloae's Trinitarian Ecclesiology, 6I-94; Idem, "Different Orthodox Perspectives on the Ecclesiological Ramifications of the Filioque: Trinitarian Ecclesiology and Eucharistic Ecclesiology," Logos: A Journal of Eastern Christian Studies 58: I-4 (2017): II-I2.

${ }_{67}$ Stăniloae, The Experience of God, Vol. III: The Person of Jesus Christ as God and Saviour, trans. Ioan Ionita (Brookline, MA: Holy Cross Orthodox Press, 20I I), 7-9.

${ }_{68}$ Stăniloae, "The Trinitarian Relations," 29-33; Coman, “Le Saint Esprit comme liaison de l'amour," 25-5I. 
practice of reading back from the 'economic Trinity' into the 'immanent Trinity';69 and (iv) the model of the threefold office of Christ which originated with Calvin.70 The space limit of this article does not all us entering into discussions on the relevance of Stăniloae's use of the image of the Holy Spirit as the love between the Father and the Son for the ecumenical dialogue but it needs to be said that his Trinitarian theology has been instrumental in bringing the East and the West much closer on the path towards a final solution to the pneumatological controversy related to the Spirit's eternal procession.7।

\section{Instead of Conclusions: Why Does All This Matter Today?}

Orthodox Christians have been engaged in the foundation of the ecumenical movement from its inception, tirelessly working towards the restoration of the unity of divided Christendom. Even though some conservative groups within Eastern Christianity looked with displeasure and suspicion at the nascent ecumenical movement, their criticism remained marginal for a long time and had no major impact upon the ecumenical trajectory of the Orthodox Church. Lamentably, over the more recent decades, Orthodoxy has been confronted with the rapid growth of anti-ecumenical and anti-Western sentiments among its members. The controversial reception of the more-ecumenically oriented statements of the Holy and Great Council of the Orthodox Church, which was convened in Crete in 2016 after many decades of preparations, shows but the explosion of fundamentalism within Orthodox communities, especially in Eastern Europe.72 In the discourses of the fundamentalists groups, Orthodoxy designates itself "in juxtaposition to others, in effect making its believers intolerant towards anything falling outside her visible boundaries." 73 As has mentioned at the beginning of this

69 Stăniloae, “The Trinitarian Relations,"21-22; V. Coman, Dumitru Stăniloae’s Trinitarian Ecclesiology, 73-75.

70 Bordeianu, Dumitru Staniloae: An Ecumenical Ecclesiology, 30-33.

7I Michael A. Fahey, 'Orthodox Ecumenism and Theology: 1978-83,” Theological Studies 44: 4 (1983): 667.

72 P. Ladouceur, “On Ecumenoclasm: Anti-Ecumenical Theology in Orthodoxy,” St. Vladimir's Theological Quarterly 61:3 (2017): 323-355.

73 Haralambos Ventis, “Fundamentalism as ‘Orthodoxism',” Public Orthodoxy, July 3, 2018. See https://publicorthodoxy.org/2018/07/03/fundamentalism-as-orthodoxism/. 
article, the agenda of the Neo-patristic movement is partly responsible for the consolidation of anti-ecumenical and anti-Western discourses in contemporary Orthodoxy, for its strong emphasis on Eastern theology's need to liberate itself from the scholastic influences of Western Christianity paved the way for the development of an Orthodoxy which is intolerant and hostile to the Christian 'Other': to find the genuine ethos of Orthodoxy, Eastern theology has to escape the captivity of Western patterns of thought, primarily scholasticism. The agenda of the Neo-patristic movement functioned, therefore, as a source of influence for fundamentalist and very conservative voices in Orthodoxy. However, a close study of Stăniloae's notion of 'open sobornicity' and its implications offers a new picture of the Neopatristic movement's attitude towards Western theology; and such a picture is crucial for the development of a different trajectory for Orthodox theology than that projected by fundamentalist and anti-ecumenical groups.

As this article has shown, even though the characterization of the Neo-patristic movement as critical of many aspects of Western thought, primarily the negative transformations brought about to Christian theology in general by scholasticism, captures an important aspect of the Orthodox ressourcement's position vis-à-vis the West, the picture is not complete. There is much more in the Neo-patristic movement's interaction with Roman Catholicism and Protestantism than its rejection of both Western scholasticism and the dividing doctrines between Eastern Orthodoxy and Western Christianity. There is the Neopatristic movement's openness to assimilate the authentic theological acquisitions of Western thought that could enrich Orthodoxy. This is to say that, if adequately researched, the agenda of the Neo-patristic movement can also pave the way to a more ecumenical Orthodoxy, which does not define itself in opposition to Western Chsitianity, but in dialogue and conversation. One may wonder at this point whether, in fact, it is allowed to claim that Stăniloae's conviction that the best in Orthodox theology is achieved with discerning receptivity towards the Christian 'other' is representative for the agenda of the Neo-patristic movement as a whole. Although Stăniloae is the only theologian who provided the Neopatristic movement with the theoretical framework for a methodology of ecumenical conversation, most of the ressourcement thinkers shared his conviction that an "independence from the non-Orthodox West [i.e., Latin Scholasticism] need not become estrangement from it. A break with the West would provide no real liberation." Georges Florovsky, the author of these lines, went on to say that the task of Orthodox theology "is not to abandon" the Western tradition "but to participate in it freely, responsibly, consciously, and openly. The 
Orthodox theologian must not, and dares not, depart from this universal circulation of theological searching." ${ }_{74} \mathrm{~A}$ similar approach is surfacing in Lossky's theology when he declares that "I have always been a 'Westerniser' [...] I could never have lived or worked in Russia, whatever the régime; I am too deeply rooted in the West, in France in particular." 75 Both Florovsky and Lossky pursued ecumenical paths similar to Stăniloae: use of Western scholarship, contacts with Roman Catholic and Protestant theologians, partly through ecumenical activities and partly on a personal basis, etc.

In fact, Stăniloae's notion of 'open sobornicity' exemplifies the struggles of the representatives of the Neo-patristic movement to hold the balance between twin fidelities.

On the one hand, faithfulness to the genuine ethos of Eastern Christianity, which finds its authentic expression in the Greek and Byzantine patristic tradition. Commitment to the vision and existential orientation of the Greek Fathers of the Church was thereby an essential guiding principle of the agenda of the architects of Orthodox ressourcement, who attempted to purify Eastern theology and spirituality from the negative influences of Latin scholasticism. Such a departure from scholasticism and its influences has been identity forming for many people in the East, for it has easily became part of the rhetoric which defined Orthodoxy in opposition to the West, leading inevitably to the growth of anti-Western and anti-ecumenical feelings.

On the other hand, faithfulness to an attitude of openness and receptivity towards whatever is good and true in the Christian 'other', as God is intensely present and works beyond the boundaries of Orthodoxy. Such an axis of interaction with the West does not want to separate Orthodoxy from the rest of the Christian world; on the contrary, it challenges any Orthodox tendency towards triumphalism, ghettoization, and self-sufficiency.

${ }_{74}$ Florovsky, The Ways of Russian Theology, vol. II (Belmont, MA: Nordland, 1979), 30I and 303; Idem, "Breaks and Links," in Brandon Gallaher and Paul Ladouceur (eds.), The Patristic Witness of Georges Florovsky: Essential Theological Writings (New York, NY: T\&T Clark, 2019), 172 and 174; John Romanides is among the very few Neo-patristic theologians who adopted a staunch anti-Westernism. See P. Gavrilyuk, "Florovsky's Neopatristic Synthesis," note 72, 308. A similar idea is expressed by Pantelis Kalaitzidis in his article titled "The West in Contemporary Greek Theology," in Orthodox Constructions of the West, 144.

75 Lossky, Seven Days on the Roads of France: June 1940, transl. Michael Donley (Yonkers, NY: St. Vladimir's Seminary Press, 2012), 96 and 98. 
It is extremely important to look at the issue of the Neo-patristic movement's interaction with Western theology in all its complexity, without forgetting none of the twin fidelities of the Orthodox ressourcement. Since the agenda of the Neo-patristic movement serves as an identity builder for contemporary Orthodox, it is imperatively necessary not to have a truncated picture of its program and theological principles. Both individually and collectively, human persons tend to over-remember and over-emphasize some aspects of the past, while, at the same time, under-remembering or even intentionally forgetting other aspects that do not fit into their identity model or vision.76 Unfortunately, the Neo-patristic movement's critique of Latin scholasticism has been over-remembered by some Orthodox conservative circles in their attempt to define Eastern Christianity by what the 'West' is not. At the same time, the ecumenical component of the same movement has completely been forgotten or ignored. For this precise reason, what this article tried to do is to offer a more comprehensive image of the Neo-patristic movement's engagement with Western theology, emphasizing that every theological act of remembering must always operate with a memory faithful to the truth of the past, making sure that no voices have been silenced, no events have been forgotten, and no central aspects have been neglected. When such a task is accomplished, instead of inspiring anti-ecumenical and anti-Western feelings, the agenda of the Neo-patristic movement, and especially Stăniloae's concept of 'open sobornicity', invites contemporary Orthodoxy to work for the implementation of an ecumenical hermeneutics of receptivity in relation to Western theology.

Even though Stăniloae's concept of 'open sobornicity' was primarily meant to provide the Orthodox Church with a tool of engaging inter-Christian dialogue, the relevance of his hermeneutics of receptivity cannot and must not be limited to the Orthodox sphere and context. Its relevance goes beyond the confines of Eastern Christianity. Undoubtedly, nonOrthodox Churches can also find in Stăniloae's concept a valuable methodology of ecumenical interaction, as the ecclesiology of communion - on which 'open sobornicity' rests - continues to serve as a normative description of church life by both Eastern and Western Christianity. Stăniloae's reflections on 'open sobornicity' represent an amplified ecclesiology of communion: by growing together towards fullness in Christ, Christian Churches get closer to one another. It suffices to mention here the names of a few Roman Catholic thinkers like

${ }_{76}$ See John Erickson, "The Temporal Dimension of Discernment: History and Memory," St. Vladimir's Theological Quarterly 63:I (2019): 7-26. 
Jerôme Hammer, Yves Congar, Karl Rahner, J.-M.-R. Tillard, Joseph Ratzinger, Hans Urs von Balthasar, Henri de Lubac, Francis A. Sullivan, Rick Gaillardetz, or Ormond Rush77 to show that the notion of the Church as communion and its derivative aspects, including the ecumenical ones, has been - and continues to be - a largely accepted ecclesiological model among Western theologians too. For example, Pope Francis' program of ecclesiological renewal attaches high priority to the notion of communion and to the ecumenical principle of learning from other Christian traditions. In Evangelii Gaudium, Pope Francis noted that, "through an exchange of gifts, the Spirit can lead us ever more fully into truth and goodness" (EG 246).78 Commenting upon the interview that the same Pope gave to Antonio Spadaro for La civiltà Cattolica (20I3), Peter De Mey remarks that, for Pope Francis, "in ecumenical relations it is important not only to know each other better, but also to recognize what the Spirit has sown in the other as a gift for us."79 That being so, Stăniloae's methodology of ecumenical interaction speaks also to a Western audience and can easily enter into conversation with Roman Catholic and Protestant theologians whose primary concern is to place the ecumenical practice of receptivity at the center of church life.

\section{Viorel Coman \\ FWO Postdoctoral Fellow \\ KU Leuven \\ viorel.coman@kuleuven.be}

\footnotetext{
77 See Dennis M. Doyle, Communion Ecclesiology: Vision and Versions (Maryknoll, NY: Orbis Books, 2000); Avery Dulles, Models of the Church (Garden City, NY: Doubleday, 1974).

78 Pope Francis, The Apostolic Exortation Evangelii Gaudium, $\S 246$. See http://www.vatican.va/content/francesco/en/apost_exhortations/documents/papafrancesco_esortazione-ap_20131124_evangelii-gaudium.htm|\#Ecumenical_dialogue 79 See "The 2019 IOTA Conference: Interview with Peter De Mey" at https:/theo.kuleuven.be/apps/press/theologyresearchnews/2019/02/06/the-2019-iotaconference-interview-with-prof-peter-de-meyl.
} 
